Constitutional Theocracy 



\section{CONSTITUTIONAL THEOCRACY}

Ran Hirschl

HARVARD UNIVERSITY PRESS

Cambridge, Massachusetts

London, England

2010 
Copyright $(9) 20$ Io by the President and Fellows of Harvard College All rights reserved

Printed in the United States of America

Library of Congress Cataloging-in-Publication Data

Hirschl, Ran.

Constitutional theocracy / Ran Hirschl.

p. $\mathrm{cm}$.

ISBN 978-0-674-04819-5

I. Constitutional law-Religious aspects.

2. Theocracy-Political aspects. I. Title.

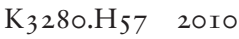

$342-\mathrm{dc22} \quad 2010000963$ 